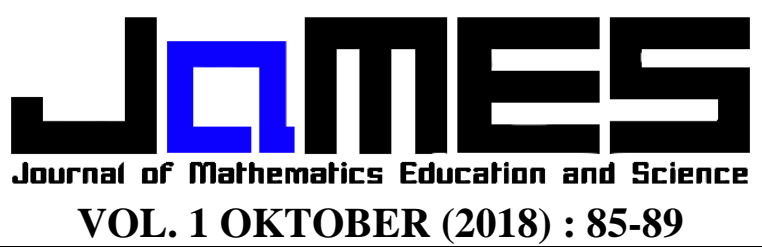

p-ISSN: 2621-1203 | https://doi.org/10.32665/james.v1iOctober.42 | e-ISSN: 2621-1211

\title{
MENINGKATKAN KEMAMPUAN PEMECAHAN MASALAH SISWA SMP MELALUI METODE PEMBELAJARAN BERBASIS MASALAH
}

\author{
Adi Ihsan Imami ${ }^{1}$ \\ Universitas Singaperbangsa Karawang, adi.ihsan@fkip.unsika.ac.id ${ }^{1}$ \\ Received : 14 September 2018, Revised : 16 Oktober 2018, Accepted : 17 Oktober 2018 \\ (C) Mathematics Education Unugiri 2018
}

\begin{abstract}
One alternative model of learning that is expected to improve problem-solving skills is the Problem Based Learning model. This research aims to examine the problem-solving abilities of junior high school students. This study is classified as Quasi Experiments that was conducted at SMP Nurul Huda in Karawang. This research was an experimental design with 80 seventh grade student as a sample, it is divided into two different classes as a Problem Based Learning class and conventional learning class. The two classes were given pretest and posttest to determine students' problem-solving abilities. The results showed that problem solving abilities students who obtained learning with Problem Based Learning were better than students who received conventional learning. The success of students in learning mathematics with Problem Based Learning and problem-solving problems shows good results.
\end{abstract}

Keyword : Problem Based Learning, problem solving

\begin{abstract}
Abstrak
Salah satu alternatif model dan pendekatan pembelajaran yang diperkirakan dapat meningkatkan kemampuan pemecahan masalahadalah model Pembelajaran Berbasis Masalah. Penelitian ini bertujuan untuk menelaah kemampuan pemecahan masalah siswa SMP. Penelitian ini termasuk Kuasi Eksperimen yang dilakukan di SMP Nurul Huda di kota Karawang, Penelitian ini adalah suatu eksperimen berdisain dengan sampel 80 siswa kelas VII pada dua kelas yang berbeda sebagai kelas Pembelajaran Berbasis Masalah dan kelas pembelajaran konvensional. Kedua kelas yang diteliti diberikan pretest dan postest untuk mengetahui kemampuan pemecahan masalah. Hasil penelitian menunjukan bahwa kemampuan pemecahan masalah yang memperoleh pembelajaran dengan Pembelajaran Berbasis Masalah lebih baik dari pada siswa yang memperoleh pembelajaran konvensional. Keberhasilan siswa terhadap pelajaran matematika dengan Pembelajaran Berbasis Masalah serta terhadap soal-soal pemecahan masalah menunjukkan hasil yang baik.
\end{abstract}

\section{Kata kunci : Pembelajaran Berbasis Masalah, Kemampuan pemecahan masalah}

\section{Pendahuluan}

Matematika merupakan salah satu ilmu bantu yang sangat penting dan berguna dalam kehidupan sehari-hari maupun dalam menunjang perkembangan ilmu pengetahuan dan teknologi. Matematika merupakan sarana berpikir untuk menumbuh kembangkan pola fikir logis, sistematis, objektif kritis dan rasional yang harus dibina sejak pendidikan dasar.

Pemecahan masalah adalah sebuah proses dimana suatu situasi diamati kemudian bila ditemukan ada masalah dibuat penyelesaiannya dengan cara menentukan masalah, mengurangi atau menghilangkan masalah atau mencegah masalah tersebut terjadi. Ruseffendi [1] menyatakan bahwa, "Sesuatu itu merupakan masalah bagi seseorang bila sesuatu itu: baru, sesuai dengan kondisi yang memecahkan masalah (tahap perkembangan mentalnya) dan ia memiliki pengetahuan prasyarat". 
Tujuan pertama untuk kebutuhan masa kini, pembelajaran matematika mengarah pada pemecahan masalah konsep-konsep yang diperlukan untuk menyelesaikan masalah matematis dan ilmu pengetahuan lainnya. Tujuan kedua untuk kebutuhan masa yang akan datang atau mengarah ke masa depan, mempunyai arti lebih luas yaitu pembelajaran matematika memberikan kemampuan nalar yang logis, sistematis, kritis, dan cermat serta berpikir objektif dan terbuka yang sangat diperlukan dalam kehidupan sehari-hari serta untuk menghadapi masa depan yang selalu berubah.

Salah satu tujuan pengajaran matematika di sekolah adalah agar siswa mempunyai kemampuan matematik yang dapat digunakan. Dengan memiliki kemampuan matematika, siswa diharapkan dapat menggunakan kemampuan-kemampuan tersebut dalam menghadapi masalah-masalah dalam berbagai bidang kehidupan. Untuk mencapai tujuan tersebut, dalam pelaksanaan kegiatan pembelajaran di kelas, guru hendaknya memilih tugas-tugas matematika, model, strategi dan pendekatan pembelajaran matematika sedemikian hingga dapat memotivasi siswa dan meningkatkan keterampilan siswa, menciptakan suasana kelas yang mendorong dicapainya penemuan dan pengembangan ide matematika, dan guru membimbing secara individual, secara kelompok serta secara klasikal. Sesuai dengan pendapat Sagala [2] bahwa guru harus memiliki metode dalam pembelajaran sebagai strategi yang dapat memudahkan peserta didik untuk menguasai ilmu pengetahuan yang diberikan. Selainitu, guru harus mengetahui kesulitan-kesulitan yang dialami siswa dalam pembelajaran matematika sehingga dapat diberikan solusi yang tepat agar tujuan dalam pembelajaran dapat tercapai

Penggunaan model pembelajaran yang sesuai adalah salah satu faktor yang mempengaruhi dalam meningkatkan kemampuan pemecahan masalah. Salah satunalternatifnya adalah dengan menggunakan model pembelajaran berbasis masalah (PBM) (problem based learning). Pembelajaran berbasis masalah adalah suatu pembelajaran yang menggunakan masalah dunia nyata sebagai suatu konteks bagi peserta didik untuk belajar tentang cara berpikir kritis dan keterampilan pemecahan masalah serta untuk memperoleh pengetahuan dan konsep yang esensial dari materi pembelajaran Nurhasanah [3]. Menurut Arends [4] PBM dirancang terutama untuk membantu siswa mengembangkan keterampilan berpikir, keterampilan menyelesaikan masalah, dan keterampilan intelektualnya. Hal ini sesuai dengan penelitian Sumartini [5] terhadap siswa SMK di Garut dengan menggunakan model pembelajaran berbasis masalah dapat meningkatkan kemampuan pemecahan masalah.

Berdasarkan latar belakang dan identifikasi yang sudah diuraikan di atas, permasalahan dibatasi pada pemecahan masalah siswa SMP diharapkan dapat diatasi dengan Pembelajaran Berbasis Masalah, sehingga permasalahan dalam penelitian ini dirumuskan sebagai berikut: Apakah pencapaian dan peningkatan kemampuan pemecahan masalah matematis siswa yang pembelajarannya menggunakan pembelajaran berbasis masalah lebih baik daripada yang menggunakan pembelajaran konvensional.

\section{Metodologi Penelitian}

Metode dalam Penelitian ini adalah suatu quasy eksperiment karena subjek penelitian tidak dikelompokkan secara acak. Penelitian ini bertujuan untuk menelaah peranan pembelajaran berbasis masalah terhadap pencapaian kemampuan pemecahan masalah siswa SMP dalam pembelajaran matematika.

Dalam penelitian ini diperlukan dua kelompok, satu kelompok sebagai kelompok eksperimen yang diberipembelajaran berbasis masalah, dan kelompok yang lain adalah kelompok kontrol yang diberi pembelajaran konvensional. Sebelum dan sesudah pembelajaran kedua kelompok di berites. Desain yang digunakan dalam penelitian ini adalah non equivalent control group design dengan ilustrasi sebagai berikut: 


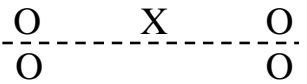

Keterangan :

$\mathrm{X}=$ pembelajaran berbasis masalah

$\mathrm{O}=$ Pemberian tes awal dan tes akhir (tes pemecahan masalah)

--------- = Pemilihan sampel tidak secara acak.

Populasi dalam penelitian adalah seluruh siswa di satu SMP Nurul Huda di Kota Karawang, sedangkan yang subjek sampel penelitian adalah siswa dari dua kelas VII dari satu SMP Nurul Huda di kota Karawang, yang dipilih dari kelas VII yang ada.

Dalam penelitian ini terdapat satu instrumentyaitu instrument kemampuan pemecahan masalah matematik. Tes kemampuan pemecahan masalah matematik berupa tes tertulis berbentuk uraian yang berjumlah 5 soal. Dengan tingkat kesukaran sedang. Tes ini diberikan pada saat pretestt dan posttest. Untuk mengetahui kemampuan awal diberikan pretest berupa soal-soal dengan materi himpunan yang berkaitan dengan pemecahan masalah.. sedangkan hasil posttest digunakan untuk melihat pencapaian dan peningkatan kemampuan pemecahan masalah.

\section{Hasil Penelitian dan Pembahasan}

Data yang diolah dan dianalisis pada penelitian ini berupa skor pretest, posttes, gain ternormalisasi untuk pemecahan masalah siswa. Berikut ini disajikan statististik deskriptif skor pretest, posttest, dan gain ternormalisasi $\langle\mathrm{G}\rangle$ dalam bentuk tabel.

Tabel 1. Statistik deskriptif kemampuan pemecahan masalah

\begin{tabular}{cccccccc}
\hline & \multicolumn{3}{c}{$\begin{array}{c}\text { Pembelajaran } \\
\text { Konvensional }\end{array}$} & \multicolumn{4}{c}{$\begin{array}{c}\text { Pembelajaran } \\
\text { berbasis masalah }\end{array}$} \\
\cline { 2 - 8 } $\begin{array}{c}\text { Varia } \\
\text { bel }\end{array}$ & $\begin{array}{c}\text { Pre } \\
\text { test }\end{array}$ & $\begin{array}{c}\text { Post } \\
\text { test }\end{array}$ & $<\mathrm{G}>$ & $\begin{array}{l}\text { Pre } \\
\text { test }\end{array}$ & $\begin{array}{c}\text { Post } \\
\text { test }\end{array}$ & $<\mathrm{G}>$ \\
\hline $\begin{array}{c}\text { Kemam } \\
\text { puan }\end{array}$ & $\bar{x}$ & 11,07 & 23,37 & 0,5 & 10 & 25,4 & 0,61 \\
$\begin{array}{c}\text { Peme } \\
\text { cahan } \\
\text { masalah }\end{array}$ & $\mathrm{S}$ & $32 \%$ & $67 \%$ & & $33 \%$ & $73 \%$ & \\
\cline { 2 - 8 }
\end{tabular}

Rerata pretest kemampuan pemecahan masalah siswa kelas yang pembelajarannya menggunakan konvensional dan pembelajaran pembelajaran berbasis masalah masing-masing adalah 11,07 sekitar $32 \%$ dan 10 atau $33 \%$. Terlihat bahwa selisih rerata pretest kedua kelompok tersebut adalah 1,07 sehingga dapat dikatakan bahwa kemampuan awal kedua kelompok kelas tidak jauh berbeda. Sebaran data untuk kemampuan pemecahan masalah siswa kelas yang pembelajarannya menggunakan konvensional dan pembelajaran pembelajaran berbasis masalah masing-masing adalah 3,6 dan 4,19. Ini berarti bahwa sebaran data kemampuan pemecahan masalah matematik siswa kelas yang pembelajarannya menggunakan pembelajaran berbasis masalah lebih besar dari kelas dengan pembelajaran konvensional.

Selanjutnya, rerata nilai posttest kemampuan pemecahan masalah siswa kelas yang pembelajarannya menggunakan konvensional dan pembelajaran pembelajaran berbasis masalah masing-masing adalah 23,37 atau sekitar $67 \%$ dan 25,4 sekitar $73 \%$. Terlihat bahwa selisih rerata posttest kedua kelompok tersebut adalah 2,13 sehingga dapat dikatakan bahwa kemampuan akhir kedua kelompok kelas berbeda dan posttest kemampuan pemecahan masalah siswa kelas yang pembelajarannya menggunakan pembelajaran berbasis masalah lebih tinggi daripada kelas dengan pembelajaran konvensional.

\section{Analisis Posttest Kemampuan Pemecahan masalah}

Skor posttest kemampuan pemecahan masalah adalah skor yang diperoleh setelah pembelajaran diberikan, baik pada kelas eksperimen maupun kelas kontrol. Adapun hasil pengolahan data dengan SPSS 21 for windows dutunjukkan pada tabel 2.

Untuk selanjutnya dilakukan uji independent $t$ test yang bertujuan untuk melihat uji perbedaan dua rata-rata antara kelas yang pembelajarannya dengan pembelajaran berbasis masalah dan kelas dengan pembelajaran konvensionl. Kriteria pengujiannya adalah Ho diterima jika nilai sig. $>\alpha$, dan Ha diterima. Sedangkan jika nilai sig. $<\alpha$, maka Ho ditolak 
da Ha diterima dengan tingkat signifikansi $\alpha=$ 0,05 . Adapun hipotesis yang diuji adalah:

Ho : pencapaian kemampuan akhir pemecahan masalah kelas yang menggunakan pembelajaran berbasis masalah tidak lebih baik dari kelas yang menggunakan pembelajaran konvensional.

Ha : pencapaian kemampuan akhir pemecahan masalah kelas yang menggunakan pembelajaran berbasis masalah lebih baik dari kelas yang menggunakan pembelajaran konvensional.

Tabel 2. Statistik Deskriptif posttest pemecahan masalah matematik

\begin{tabular}{cc}
\hline Kelas & $\begin{array}{c}\text { Kemampuan } \\
\text { Pemecahan } \\
\text { masalah }\end{array}$ \\
\hline & $\bar{x}$ \\
Pembelajaran Konvensional & 23,37 \\
Pembelajaran berbasis masalah & $67 \%$ \\
& 25,4 \\
\hline
\end{tabular}

Keterangan: Skor ideal untuk kemampuan pemecahan masalah adalah 35 .

Hasil perhitungan uji independent $t$ test ini diperlihatkan pada tabel 3 di bawah ini:

Tabel 3. Uji independent $t$ test Skor posttest Kemampuan pemecahan masalah t-test for Equality of Means

\begin{tabular}{lllll}
\hline & & t-test for Equality of Means \\
\cline { 3 - 5 } & & & Df & $\begin{array}{l}\text { Sig. (2- } \\
\text { tailed) }\end{array}$ \\
\hline posttest & $\begin{array}{l}\text { Equal } \\
\text { variances } \\
\text { assumed }\end{array}$ & $-2,216$ & 78 &, 030 \\
\cline { 2 - 5 } & $\begin{array}{l}\text { Equal } \\
\text { variances } \\
\text { not assumed }\end{array}$ & $-2,216$ & 74,275 &, 030 \\
\hline
\end{tabular}

Tabel di atas memperlihatkan bahwa nilai sig. Adalah 0,030 karena dalam tampilan nilai signifikansi dari SPSS adalah uji dua pihak (two tailed), sehingga untuk uji satu sisi (one tailed) kita harus membagi dua menjadi $\frac{0,030}{2}=0,015$. Ini berarti bahwa hipotesis Ho ditolak dan $\mathrm{Ha}$ diterima . Jadi, dapat disimpulkan bahwa untuk posttest kemampuan pemecahan maslaah dengan pembelajaran berbasis masalah lebih baik dari kelas pembelajaran konvensional.

\section{Analisis Gain Ternormalisasi Kemampuan Pemecahan Masalah}

Analisis gain ternormalisasi dimaksudkan untuk melihat peningkatan kemampuan pemecahan masalah siswa yang pembelajarannya menggunakan pembelajaran berbasis masalah dan pembelajaran konvensional. Data gain ternormalisasi berasal dari selisih skor posttest dengan skor pretest dari masing-masing skor tes kemampuan pemecahan masalah.

Berikut ini disajikan statistik deskriptif gain ternormalisasi kemampuan pemecahan masalah dengan menggunakan program SPSS 21 for windows :

Tabel 4. Statistik Deskriptif Gain Ternormalisasi Kemampuan Pemecahan masalah matematik Siswa

\begin{tabular}{ll}
\hline Kelas & $\begin{array}{c}\text { Kemampuan } \\
\text { Pemecahan } \\
\text { masalah }\end{array}$ \\
\cline { 2 - 2 } & \multicolumn{1}{c}{$\bar{x}$} \\
\hline Pembelajaran Konvensional & 0,5 \\
\hline Pembelajaran Berbasis masalah & 0,61 \\
\hline
\end{tabular}

Untuk selanjutnya dilakukan uji independent $t$ test yang bertujuan untuk melihat uji perbedaan perbedaan peningkatan kelas yang pembelajarannya dengan pembelajaran berbasis masalah dan kelas dengan pembelajaran konvensionlAdapun hipotesis yang diuji adalah:

Ho : Peningkatan kemampuan pemecahan masalah siswa yang menggunakan pembelajaran berbasis masalah tidak lebih baik daripada siswa menggunakan pembelajaran konvensional.

Ha : Peningkatan kemampuan pemecahan masalah siswa yang menggunakan pembelajaran berbasis masalah lebih baik daripada siswa menggunakan pembelajaran konvensional. Hasil perhitungan uji Mann Whitney ini diperlihatkan pada tabel 5. 
Tabel 5. Uji Mann Whitney Gain Ternormalisasi Kemampuan pemecahan masalah

\begin{tabular}{|c|c|c|c|c|}
\hline & & \multicolumn{3}{|c|}{$\begin{array}{c}\text { t-test for Equality of } \\
\text { Means } \\
\end{array}$} \\
\hline & & $\mathrm{T}$ & Df & $\begin{array}{l}\text { Sig. (2- } \\
\text { tailed) }\end{array}$ \\
\hline \multirow[t]{2}{*}{ Gain } & $\begin{array}{l}\text { Equal variances } \\
\text { assumed }\end{array}$ & 2,714 & 78 & ,008 \\
\hline & $\begin{array}{l}\text { Equal variances } \\
\text { not assumed }\end{array}$ & 2,714 & 77,735 &, 008 \\
\hline
\end{tabular}

Tabel di atas memperlihatkan bahwa nilai sig $=0,008$ karena dalam tampilan nilai signifikansi dari SPSS adalah uji dua pihak (two tailed), sehingga untuk uji satu sisi (one tailed) kita harus membagi dua menjadi $\frac{0,008}{2}=0,004$. $<0,05$, ini berarti bahwa hipotesis Ho ditolak dan Ha diterima. Jadi, dapat disimpulkan bahwa Peningkatan kemampuan pemecahan masalah siswa yang menggunakan pembelajaran berbasis masalah lebih baik daripada siswa menggunakan pembelajaran konvensional.

\section{Penutup}

Berdasarkan analisis data dan pembahasan yang telah dikemukakan pada bab sebelumnya, diperoleh beberapa kesimpulan sebagai berikut : Pencapaian dan peningkatan kemampuan pemecahan masalah siswa yang memperoleh Pembelajaran Berbasis Masalah lebih baik daripada kemampuan siswa dengan pembelajaran konvensional. Hal tersebut dilihat dari pencapaian rata-rata skor posttest kemampuan pemecahan pada kelas Pembelajaran Berbasis Masalah dan peningkatan dilihat dari gain pretest dan posttest kemampuan pemecahan matematis pada kelas Pembelajaran Berbasis Masalah. Kemampuan pemecahan masalah siswa pada kedua kelas sebelum diberikan Pembelajaran Berbasis Masalah dapat dikategorikan dalam tingkatan yang rendah sedangkan pada kelas yang diberikan pembelajaran konvensional dikategorikan dalam tingkatan rendah. Setelah diberikan Pembelajaran Berbasis Masalah mengalami pencapaian peningkatan yang dapat dikategorikan sedang dan pada kelas pembelajaan konvensional masih dikategorikan rendah.

Berdasarkan hasil dari penelitian ini, selanjutnya dikemukakan saran-saran sebagai berikut:

1. Pembelajaran Berbasis Masalah hendaknya dijadikan alternatif pembelajaran di sekolah terutama untuk siswa sekolah peringkat tinggi dan sedang dalam pembelajaran topik-topik tertentu terutama topik-topik baru yang berkaitan dengan topik-topik sebelumnya yang sudah dipelajari siswa, sehingga pembelajaran matematika menjadi lebih bermakna.

2. Pembelajaran Berbasis Masalah hendaknya dijadikan alternatif pendekatan pembelajaran di sekolah terutama untuk siswa, dikarenakan Pembelajaran ini dapat merangsang siswa untuk belajar mandiri dalam mengatasi kesulitan belajar sendiri maupun kelompok.

\section{Referensi}

[1] Ruseffendi, E. T., Penelitian Pendidikan dan Hasil Belajar Siswa Khususnya dalam Pengajaran Matematika, Bandung: Tarsito. (1988).

[2] Sagala, Syaiful., Konsep dan Makna Pembelajaran, Bandung: Alfabeta. (2011).

[3] Nurhasanah, Pembelajaran Berbasis Masalah Untuk Meningkatkan Penguasaan Konsep Berpikir Kritis dan Sikap Ilmiah Siswa SMA, Tesis PPs UPI, tidak diterbitkan, (2009).

[4] Arends, Richard, Learning to Teach: Belajar untuk Mengajar. (2008).

[5] Sumartini, T, Peningkatan Kemampuan Pemecahan Masalah Matematis Siswa melalui Pembelajaran Berbasis Masalah, Jurnal Pendidikan Matematika STKIP Garut Volume 5, (2016). 
http://journal.unugiri.ac.id/index.php?journal=JaMES 